\title{
Advantages of Water Fog Use as a Fire Extinguisher
}

\author{
KUTI Rajmund ${ }^{1}$
}

\begin{abstract}
Due to the consequences of global climate change and complex impacts of civilization, the Earth's drinking water reserves have started to decrease or become so seriously contaminated in some areas that it is inadequate for human consumption. International research groups and organizations are calling the countries to greater environmental and security awareness. Severity of environmental protection regulations made the usage of environmental friendly fire-fighting materials (water, among others) more important again. In Hungary, fire brigades use drinking water in approximately $90 \%$ of their fire-fighting operations. Some recently developed water fog fire extinguisher apparatuses have made special utilization of water available, as their use is friendly to the environment, effective and economical and in comparison with the conventional fire-fighting techniques consume a considerably less amount of water. In my paper I am going to demonstrate and summarize the advantages of water fog fire extinction based on the physical and chemical properties of water.
\end{abstract}

Keywords: water, water fog, fire extinguishing effects, effectiveness, economy, environmental protection

\section{Preface}

Environmental protection aspects and environmental awareness have become more and more important in the last few years even in the field of fire-fighting. After the elimination of the halons $^{2}$ as an extinguishing agent, research and development of new fire-fighting technologies and their practical implementation have become necessary. The use of water has come to forefront again, but not in the conventional way but in water fog form. Water fog extinguishing systems make the use of water available in a special way making it more effective and non-dangerous to humans and the environment.

Fire fighters recognized during the development of fire extinguishing that the heat draining capability of water can be increased with the use of a cloud of small water particles instead of a closed water mass on the burning material. With the use of improved fire extinguishers, pumps and fire hose directors it is possible to get vaporized water at a appropriate pressure to extinguish fires more effectively.

It has been well known how to generate gentle fog-like water spray using different nozzles for a long time now, but in most cases its kinetic energy is not enough, despite the proper

1 kutir@mtk.nyme.hu

2 Halon: Haloalkan, or halogenoalkane, a group of chemical compounds consisting of alkanes with linked halogens. Halon is a liquefied, compressed gas that very effectively stops the spread of fires by chemically disrupting combustion. Production of halons was internationally ceased from 1994 due to their degrading effect on the ozone layer. 
particle sizes, so effective injection of the water spray into flames is not an easy task. Smaller water particles can be easily driven by the hot, upstream gas flow or vaporized by the heat radiation too early at the periphery of the flames, so their fire extinguishing effect is not generated.

\section{Physical and Chemical Properties of Water Fog and Its Fire Extinguishing Effects}

The key to fire extinguishing effectiveness of water fog lies within the appropriate kinetic energy of its extremely small particles. "Water fog" is the name of the aerosol, if it contains particles with a diameter of $1,000 \mathrm{~mm}$ or bigger less than $1 \%$ of the water, measured in 1 meter distance from the spray nozzle. Sizes of water particles should be checked with a laser measurement instrument at least in 24 different points in the aerosol. [1]

Fire extinguishing effect means formation of circumstances that could restrain or inhibit combustion or its formation. Water fog is an extremely useful extinguishing agent that can be used in a wide range of applications, except some special cases, where it is forbidden to use water. Its effectiveness comes from its fire extinguishing capability and from more different aspects. A series of experiments prove that different fire extinguishing effects appear at the same time using water fog.

When using water fog for fire extinguishing, water particles in a combustion zone should be as small as possible, this way maximizing the surface of the extinguishing agent, so the cooling effect is greater and the necessary amount of water is much less compared to traditional fire extinguishing methods using water flush.

It is possible to generate water fog in several pressure ranges using different spray nozzles, but there will be differences in the sizes of water particles in the aerosols. And particle size affects the active cooling surface. [2] Sizes, numbers of water drops and an active cooling surface related to 1 liter of water can be seen in Table 1 .

Table 1. Active surface is growing as the particle size decreases. [5: 1-7]

\begin{tabular}{|c|c|c|}
\hline $\begin{array}{c}\text { Size of water drops } \\
(\mathrm{mm})\end{array}$ & Number of water drops & $\begin{array}{c}\text { Active surface related to 1 liter of } \\
\text { water }\left(\mathrm{m}^{2}\right)\end{array}$ \\
\hline 10 & 1,900 & 0.6 \\
\hline 1 & $1,900,000$ & 6 \\
\hline 0.1 & $1,900,000,000$ & 600 \\
\hline 0.01 & $1.9 \mathrm{E} 12$ & $\mathbf{x 1 0}$ \\
\hline \multicolumn{3}{|c|}{ Getting down a magnitude order } \\
\hline
\end{tabular}




\section{Cooling Effect of Water Fog}

During the combustion process the majority of the liberated heat energy is passed from the combustion zone with heat conduction, heat radiation and heat convection. The remaining energy is necessary for further combustion that is $8-16 \%$ of the original. If we can decrease the temperature below the burning point (or flash point, in case of a flammable liquid) delivering an extinguishing agent into the flame zone, there will not be enough energy in the combustion area to maintain burning. The most successful way to do this is to drain heat by evaporation. In this case, part of the water fog becomes steam in the combustion zone. Due to the upthrust generated by the evaporation the convective stream of water vapor leaves the combustion zone and becomes liquid again emanating the transported heat in a distance. Size of water particles is very important in this case, because processes of heating till boiling point and evaporation happen on the surface.

Small water drops that remain in the combustion zone in liquid form have a further cooling effect due to heat drain. In this case efficiency of cooling is worse than by evaporation. So it really matters what the ratio of evaporation and simple cooling is during fire extinguishing. [2] Very small water particles mean large specific surface but are also useless, because larger fires have such intensive gas flow that the extinguishing agent cannot enter the combustion zone deep enough, so fire extinguishing is not sufficient.

Investigation of cooling effect revealed that vaporization of water at high pressure results in a much better cooling surface compared with the use of traditional, so called sprinkler devices. Intensive cooling means an advantage not only in fire extinguishing, but also by draining heat this way and protecting persons and assets on site from dangerous warmth.

\section{Oxygen Squeeze out Effect of Water Fog}

Small water particles in fire quickly become steam. This procedure happens in the flame zone on high temperatures. On lower temperatures, for example on evacuation routes, steam does not form. It is a great advantage during the use of water fog, because presence of oxygen is essential for a safe escape of personnel without SCBA. ${ }^{3}$

Water drops coming from traditional sprinklers evaporate much slower. Ideally small particles of water fog can result in a 300 times quicker evaporation speed. Evaporation and steam formation happens only in high temperature areas and the volume of water can increase up to 1,750 times higher than in liquid form, this way squeezing out oxygen from the combustion zone. Evaporation during combustion can help the entering of appropriate water fog particles into the flames. To stop fire it is necessary to decrease oxygen concentration on ambient pressure below $16 \%$. In this case water fog works very similarly to inert extinguishing gases, nitrogen or argon (inertisation effect). [3]

With the use of water fog, burning material can be covered with fog first, than with a steam cloud, blocking the entrance of oxygen into the combustion zone. This extinguishing effect becomes more obvious with the use of water fog than with traditional water use.

3 SCBA - self-contained breathing apparatus 


\section{Inhibition Extinguishing Effect of Water Fog}

The procedure of burning at high temperatures is a very complex phenomenon. In addition to oxidation, it is a chain reaction with the key presence of activated, free ions and radicals with a very short lifetime. In case of vaporization at a high pressure, ions are also forming from water molecules. These ions can recombine with other positive and negative ions and free radicals present in the combustion zone. This recombination can suspend the chain reaction of burning. In this case the process is called homogeneous inhibition.

New research and practical experiments showed that there is also a heterogeneous inhibition using water fog. This means that water particles entering the combustion zone are acting like a wall simply blocking the chain reaction of burning to pass on, so the fire stops. The inhibition extinguishing effect depends on the result of vaporization.

\section{Hitting Effect of Water Fog}

Universal fire hose directors or fire extinguisher lances of mobile water fog fire extinguishers working with combustion engines are suitable to create concentrated water fog jets. Water fog coming with great kinetic energy can rip the flames off the burning material this way disrupting the surface of the fire. A concentrated water jet is uninterrupted, has a small diameter and high speed even with the use of water fog, so it has a great hitting power and medium range. Using a concentrated water fog jet it can pass the flame zone with lower efficiency, but still can be used to disrupt smaller fires. Nevertheless, its complex extinguishing effects can not show up totally, because its surface in contact with the fire is too small and the contact time is too short.

\section{Possible Fire Extinguishing Applications of Water Fog}

Basically, water fog can be used in case of fires of all flammable materials, where water is allowed, but with special attention during wintertime to the danger of freezing.

It was confirmed by experiments that even fires of charged electric devices can be extinguished with the use of water fog with appropriate high pressure. Lately, built-in water fog extinguishers (as substitutes for halons) were designed and installed into electric stations, command rooms, digital server centers and telephone exchanges. [4]

A disadvantage of water fog use for fire extinguishing is that some chemicals can react with water and an explosion can be a result of the reaction. Alkali metals and earth metals are in this group such as sodium, potassium or magnesium, and also their carbides and hydrides.

Other sources of danger during the use of water fog can be that at a high temperature, for example in case of extinguishing metal fires, thermal dissociation of water can happen. High temperature causes degradation of water to its components, gaseous hydrogen and oxygen forming detonating gas $(2 \mathrm{H} 2+\mathrm{O} 2$, oxyhydrogen) this way, which can fuse to become water again causing an explosion. Of course, this cannot happen with the use of built-in water fog extinguishers, because it is forbidden to install them in such an environment. In case of mobile water fog extinguishers, they must not be used to extinguish metal fires.

Basically, high surface tension value of water is not advantageous for fire extinguishing. This problem arises in case of water fog also, but only marginally. Compared with the traditional utilization, using water fog means a greater surface for the same amount of water, so surface tension is a smaller problem. [5] 
A well-known phenomenon is that liquids in gases or in other liquids, which are immiscible with them, try to be in spherical form because it has the minimal surface for a given volume. This way surface tension is a kind of resistance against the force that tries to enlarge the surface of the liquid. So surface tension is a kind of force that affects within the length of the surface and tries to decrease its area. Its dimension is Newton/meter.

During fire extinguishing, water drops try to form spheres to minimize their surfaces, that is why they contact burning material's surfaces minimally, so they are not wetting the surface of the burning material adequately. That is why surface tension of water must be decreased by adding some wetting or moisturizing agents. These agents change the ratios in the cohesion forces, so the force between burning surfaces and water drops get bigger than among the water drops themselves. This way water drops can stick to burning surfaces more easily, water can even impregnate porous bodies, increasing evaporation and cooling. During fire extinguishing it is usually realized by mixing a foaming material in $1 \%$ of the water amount flowing thru the pump.

In Table 2 you can see the utilization possibilities of normal water jets, water fog and different extinguishing materials.

Table 2. Different fire extinguishing materials and their utilization possibilities. [2]

\begin{tabular}{|c|c|c|c|c|c|c|c|}
\hline & $\mathbf{A}$ & B & $\mathbf{C}$ & D & $\mathbf{E}^{*}$ & Notice & Versatility \\
\hline \multicolumn{8}{|l|}{$\begin{array}{l}\text { Extinguishing } \\
\text { materials }\end{array}$} \\
\hline Concentrated water jet & +3 & -2 & 0 & -2 & -2 & $\begin{array}{c}\text { Damages caused } \\
\text { by water }\end{array}$ & 1 \\
\hline Diffused water jet & +2 & $+1 / 0$ & $+1 / 0$ & -1 & -1 & $\begin{array}{l}\text { Smaller damages } \\
\text { caused by water }\end{array}$ & 1 \\
\hline Water fog & $+2 /+1$ & $+2 /+1$ & $+2 /+1$ & +1 & +1 & No damages & 4 \\
\hline $\begin{array}{l}\text { Fire extinguishing } \\
\text { foam }\end{array}$ & +2 & +3 & 0 & -1 & -2 & $\begin{array}{c}\text { Environmental } \\
\text { damages }\end{array}$ & 2 \\
\hline $\begin{array}{l}\text { Flame extinguishing } \\
\text { powder }\end{array}$ & $+1 / 0$ & +2 & +3 & $0 /-1$ & +1 & $\begin{array}{l}\text { Contamination, } \\
\text { panic because of } \\
\text { dust }\end{array}$ & 2 \\
\hline $\begin{array}{l}\text { Embers extinguishing } \\
\text { powder }\end{array}$ & +2 & +2 & +3 & +1 & -1 & $\begin{array}{c}\text { Contamination, } \\
\text { panic because of } \\
\text { dust }\end{array}$ & 3 \\
\hline $\begin{array}{l}\text { Metal extinguishing } \\
\text { powder }\end{array}$ & 0 & 0 & 0 & +2 & 0 & Contamination & 1 \\
\hline $\begin{array}{c}\text { Carbon } \\
\text { dioxide gas }\end{array}$ & 0 & 0 & +3 & 0 & +3 & Risk of choking & 2 \\
\hline $\begin{array}{c}\text { Carbon } \\
\text { dioxide snow }\end{array}$ & 0 & +2 & +1 & 0 & +3 & Cold shock & 2 \\
\hline Halons & +1 & +2 & +2 & -2 & +3 & $\begin{array}{l}\text { Damage to } \\
\text { ozone layer }\end{array}$ & 3 \\
\hline
\end{tabular}


Legend:

- *In presence of electric current,

- +3 excellent fire extinguishing,

- +2 good fire extinguishing,

- +1 limited use only,

- O not adequate,

- -1 utilization is worth considering,

- -2 utilization is dangerous,

After the comparison of the above data, it can be seen that water fog is a useful, very versatile fire extinguishing agent and at the same time it is environmentally friendly. It should be noticed that in the presence of an electric current only the built-in water fog fire extinguishers can be used with the maximum observance of all security precautions. [6]

\section{Conclusion}

Formation of water fog and use of water fog fire extinguishers provide new solutions in fire protection with the combination of positive properties of traditional gaseous and sprinkler extinguishers. The successfulness of fire extinguishing with water fog aerosols based on their water drop size reduction, increased kinetic energy and distribution of drops, and besides the cooling effect on the burning surface the sudden evaporation of water drops results in reduced oxygen concentration in the vicinity of the fire. What is more, in parallel with these, both homogenous and heterogeneous inhibition take place, resulting in a break in the chain reaction of burning. So this environmental friendly and very effective way of fire extinguishing is harmless for humans and causes no water damage faces a great future in fire protection.

\section{References}

[1] NAGY Gy.: Vízköddel oltó berendezések, Védelem, 1 (2000).

[2] KUTI R.: Vizköddel oltó berendezések speciális felhasználási lehetöségei és hatékonyságuk vizsgálata a tüzoltás és kárfelszámolás területén. Budapest: ZMNE, 2009. (Ph.D.

Dissertation)

[3] FOGTEC: The Smarter Way of Firefighting. Köln: FOGTEC Brandschutz GmbH and Co. KG, 2006.

[4] NÁDOR A.: Vízködös oltórendszerek - nem árt ismerni, mit miért választunk. In. Védelem Online - Tanulmányok, 51, 2008. www.vedelem.hu/letoltes/tanulmany/tan51.pdf (downloaded: 0503 2015)

[5] KUTI R.: Miben rejlik a vízköd tüzoltási hatékonysága? In. Védelem Online - Tanulmányok, 501, 2014. www.vedelem.hu/letoltes/tanulmany/tan501.pdf (downloaded: 0703 2015)

[6] KUTI R., FÖLDI L.: A beépített vízköddel oltó rendszerek újabb alkalmazási lehetőségeinek feltárása. Hadmérnök, III 2 (2008), 60-66. www.hadmernok.hu/archivum/2008/2/2008_2_ kuti.pdf (downloaded: 0705 2015) 